\title{
Mapping Buried Stream Valleys in Philadelphia, Pennsylvania
}

\section{Introduction}

In June 1999, U.S. Senator Arlen Specter (Pennsylvania) included language in the Senate Report accompanying the Interior Appropriations bill for FY 2000 requesting that the U.S. Geological Survey (USGS) and the U.S. Army Corps of Engineers (ACOE), Philadelphia District, investigate subsidence in Philadelphia. Specifically requested were a preliminary evaluation of geologic factors that control recent ground subsidence in the Wissinoming neighborhood (fig. 1) and recommendations for more comprehensive geologic studies that will be required to design a remediation effort and to delineate other neighborhoods that are potentially at risk.

\section{The Geology Tells a Story}

The geologic map from Bascom and others (1909) shows that the Philadelphia area is underlain by three distinct geologic rock types: (1) the limestone and sandstone rocks of the Northern Piedmont, (2) the complex

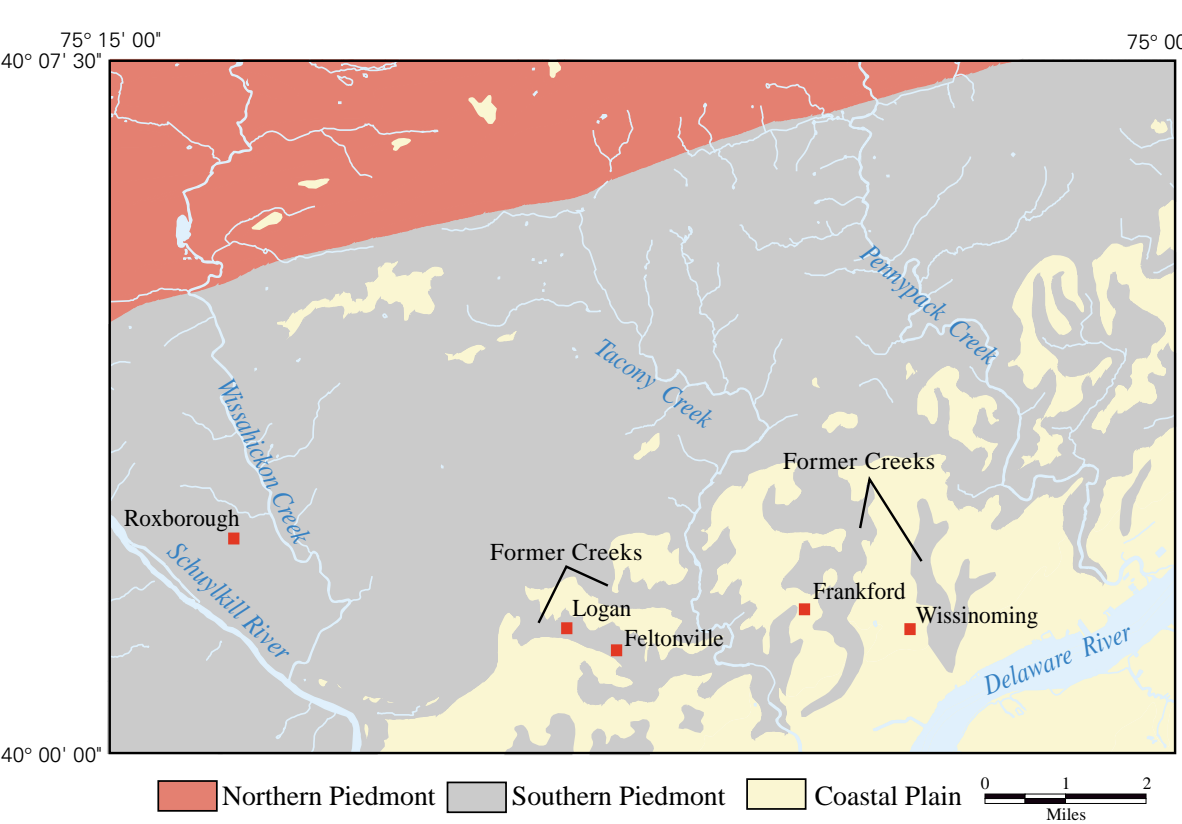

Figure 2. Generalized geologic map of the Philadelphia area showing three physiographic provinces, which are underlain by different rock types. Modified from Bascom and others (1909). metamorphic bedrock of the Southern Piedmont, and (3) layers of sediments that occupy the Coastal Plain (fig. 2). The limestone and sandstone rocks of the Northern Piedmont were deposited in an ancient shallow marine environment and are approximately half a billion years old. The metamorphic bedrock of the Southern Piedmont ranges from half a billion to more than one billion years in age and was shaped by the extreme heat and pressure of geologic forces deep in the Earth. Within the Coastal Plain, sediments were deposited during the last 75 million years, forming a layer of sand and gravel on top of the older Southern Piedmont metamorphic bedrock.

During the last million years, streams flowing into the Delaware River began to erode the sediment layer. These streams have cut down more than 60 feet in places through the sediments and into the underlying bedrock, forming stream valleys. Figure 2 shows stream valleys for Tacony and Pennypack

$75^{\circ} 00^{\prime} 00^{\prime \prime}$

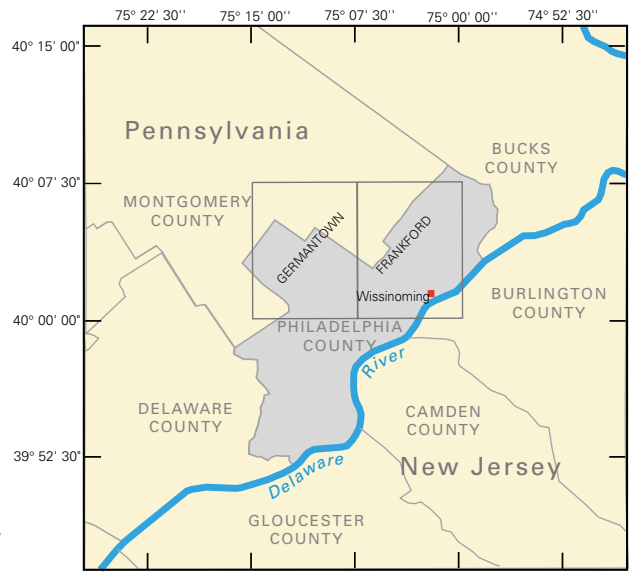

Figure 1. Location of the Frankford and Germantown quadrangles, surrounding counties, and the Wissinoming neighborhood. The city of Philadelphia is coextensive with Philadelphia County (highlighted).

Creeks, which cut through the sediment layers and are now flowing on the bedrock into the Delaware River. The stream valley boundaries are roughly outlined by places where metamorphic bedrock is now exposed through the sediment layers. In the Wissinoming area, sediments have been eroded, exposing strips of bedrock, but there are no creeks there today. These are examples of former creeks that have been filled in by man, since the production of the 1909 geologic map, to provide land area for urban development.

Questions have been asked about whether the subsidence of houses in the Wissinoming area and other neighborhoods in Philadelphia might be due to earthquakes or the natural formation of sinkholes. The possibility that earthquakes caused ground shaking and house collapse in the Philadelphia area can be ruled out because there have been no earthquakes in the 20th century in this area of sufficient size or intensity to produce the observed subsidence. Natural sinkholes form by the collapse of rock into underground caverns created by the 
dissolving away of limestone. Sinkholes are found between Easton and Harrisburg and in parts of the Northern Piedmont where limestone is common. However, areas of significant subsidence in the city of Philadelphia do not correspond to known occurrences of limestone.

The geology in figure 2 reveals that the locations of old stream valleys coincide with places where subsidence has occurred. This coincidence suggests that the subsidence is occurring in fill that occupies former stream valleys. However, the geologic map by Bascom and others (1909) does not provide enough information to evaluate the extent of filled-in valleys in Philadelphia. The USGS concluded that one method to refine the calculation of fill would be the comparison of historic and current topographic maps.

After the USGS completed the preliminary geologic evaluation, the ACOE asked the USGS to develop a map for the Frankford and Germantown quadrangles (fig. 1) that would show the extent of former stream valleys that may have been filled. The final report and map are designated USGS Open-File Report 00-224, "Geographic Information Systems Analysis of Topographic Change in Philadelphia, Pennsylvania, During the Last Century," which is available at http://pubs.usgs.gov/openfile/of00-224/

\section{What Is Fill?}

Fill can be described as a variety of materials, such as dirt or soil, that are added to the natural landscape. This modification is most often used to create suitable building sites and embankments and ramps for road and highway construction. When fill has been properly compacted according to accepted engineering practices, it is stable and forms an acceptable base for construction. However, some fill may be composed of inappropriate components and may be poorly compacted. This type of fill may settle over long periods of time. Settlement may be increased by placing a structure on the fill. Only through a site-specific investigation can the stability and engineering characteristics of fill be determined and, if necessary, remediation planned.

\section{Topographic Maps}

A topographic map portrays the shape and elevation of the land surface through the use of contour lines that connect points of equal elevation. Labels along sets of contour lines indicate the elevation above sea level. Topographic maps show natural features such as mountains, valleys, lakes, rivers, and vegetation. They also identify manmade features, such as roads, boundaries, major powerlines, and buildings. The wide range of information provided on topographic maps and the different map scales and sizes available make the maps extremely useful for engineering, conservation, planning, and outdoor activities such as hiking, camping, and fishing.

\section{Topographic Maps Highlight Change}

Topographic maps were used to identify areas where streams and other natural landscape features have changed significantly over time. Historical and current topographic maps were used to create models of topography. The oldest map used is the USGS topographic map of the Germantown quadrangle surveyed in 1889 (published in 1899) that shows Philadelphia as it appeared prior to the urban growth in the early part of the 20th century (fig. 3). The current maps are the USGS topographic maps of the Frankford and Germantown quadrangles published in 1997 (fig. 3). The two 1997 maps depict the southern half of the area shown in the single 1899 map.

Elevation data from the two sets of topographic maps were loaded into a geographic information system (GIS). The GIS created and compared digital models of topography from both historical and current maps. Figure 4 illustrates the process and the resulting topographic change map, which identifies areas of positive topographic change where there was evidence of an increase in the level of the land surface.

After completing the GIS analysis of topographic change, the USGS conducted field surveys to identify and correct possible errors in the historical data set that may have resulted from the use of less accurate surveying techniques during the 19th century. The identifica-
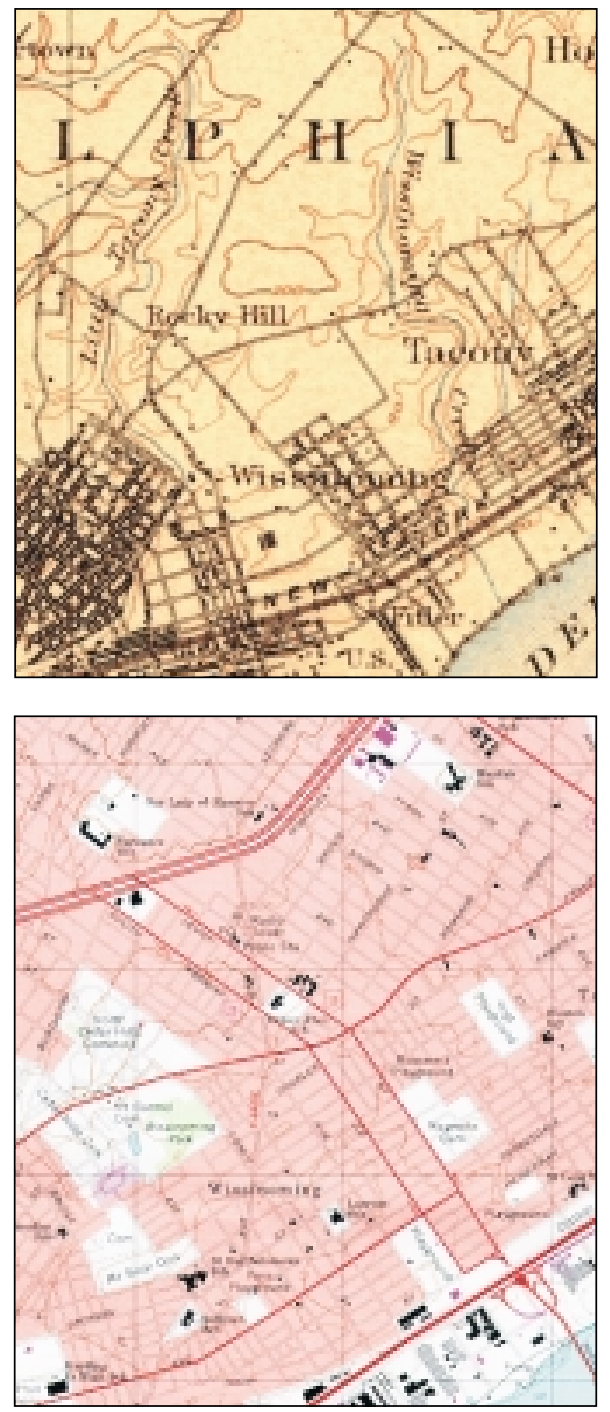

Figure 3. Parts of USGS topographic maps of the Wissinoming neighborhood, Philadelphia: historical Germantown quadrangle published in1899 (top) and current Frankford quadrangle published in 1997 (bottom).

tion process, called ground truthing, entailed the use of Global Positioning System (GPS) satellite data receivers to calculate actual ground elevations throughout the study area. The GPS survey detected some vertical discrepancies in the historical topographic data set due to misrepresentation of topography.

These misrepresentations were corrected in the GIS by a localized stretch-and-fit operation that is explained in USGS Open-File Report 00-224.

\section{Reconstructing Old Stream Valleys}

The next step was to add information about the size and location of old stream valleys that appeared on historical survey maps of the city of Philadelphia and on the 1899 USGS topographic 

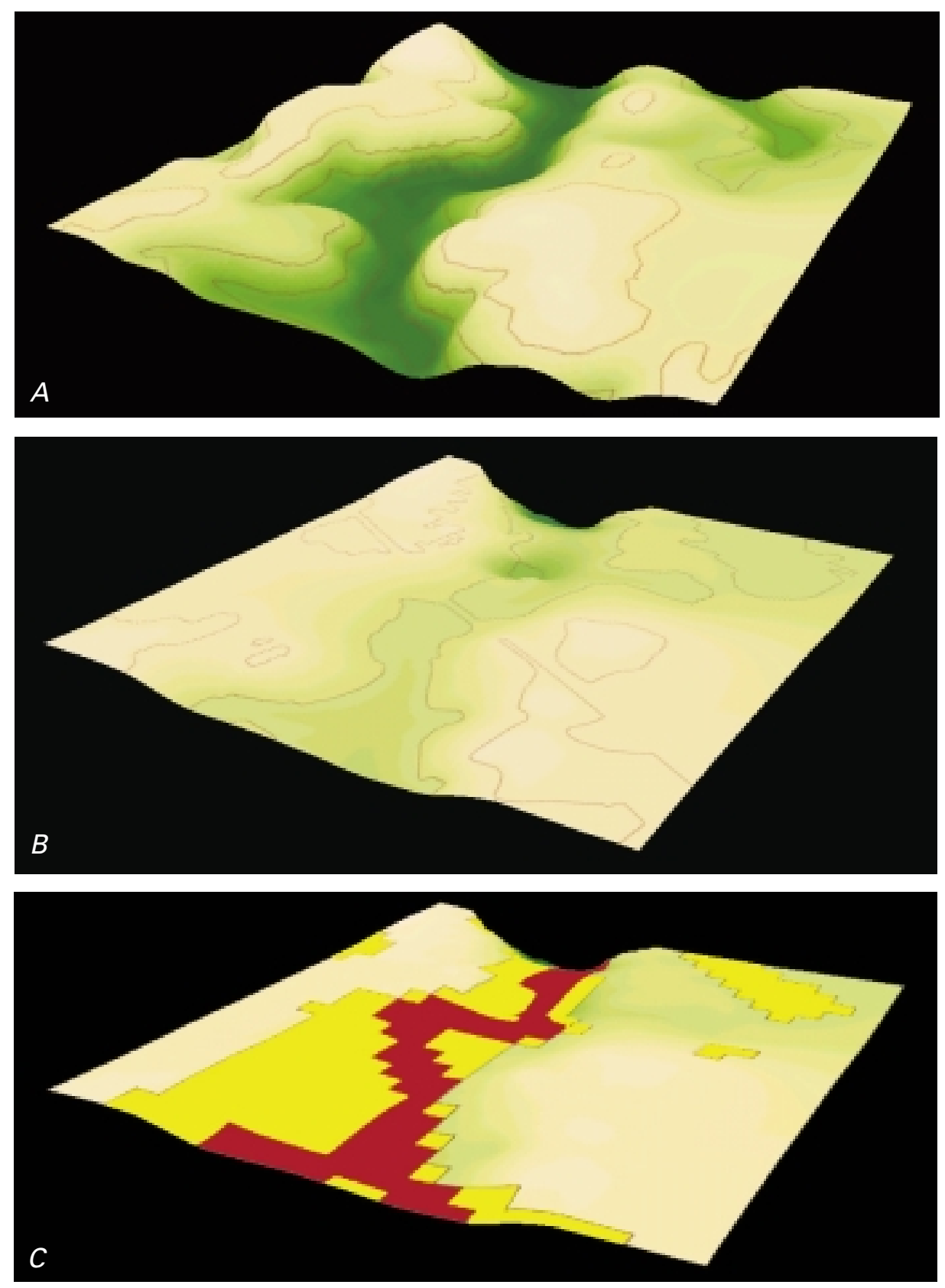

Figure 4. Models of historical and current topography and a topographic change map for Wingohocking Creek near the Logan neighborhood, Philadelphia (fig. 2). $A$, Topographic model for 1899 where green shading shows lower areas. B, Topographic model for 1997. $C$, Topographic change map showing areas that may have been filled by 1997 as indicated by the GIS comparative analysis: bright yellow, possible fill; red, probable fill.

map of the Germantown quadrangle.

Streams that may have been buried during urbanization are an important component of the topographic change model. The stream channel widths were estimated from geologic map data and then loaded into the topographic change model to help verify the horizontal distribution of possible fill areas.

\section{Topographic Change Map of Philadelphia}

GIS map data representing topographic change and historical stream probable extent of filled-in stream valleys and topographically low areas is provided in the detailed map shown in Open-File Report 00-224. Examples from the map are shown in figure 5.

The topographic change map uses pixels or cells to delineate possible fill areas. The pixel size is 50 meters by 50 meters (164 feet by 164 feet). The resolution of the data is appropriate for a regional analysis, but the data should not be used for site-specific evaluation because of inaccuracies in the historical topographic data. The inaccuracies of the historical data set and the method used to correct them are explained in Open-File Report 00-224.

\section{Subsidence Risk Is Not Shown}

It is important to note that the exact location of the fill, its total thickness or depth, its engineering characteristics, and the nature of ground-water movement need to be ascertained to judge the potential risk for subsidence or settling of the ground. Zones designated as possible or probable fill do not indicate the occurrence of nor the potential for structural subsidence. Specifically, the map does not show depth of fill, the composition of the fill material, ground-water behavior, or any engineering characteristics of sites located in or near fill areas.

\section{How to Use the Topographic Change Map}

The topographic change map in USGS Open-File Report 00-224 delineates areas that may have been physically modified through 100 years of Philadelphia's urbanization and is a guide to where buried stream channels may be located. Examples from the topographic change map in figure 5 show several historical stream valleys and topographically low areas as well as transportation features such as rail lines and interstate highways, which tend to coincide with fill areas. The topographic change map should be used as a planning and management tool to guide site-specific studies aimed at determining subsidence risk. Investigations of particular areas of interest and their historical development would prove beneficial to explaining the spatial distribution of topographic change associated with urbanization. 


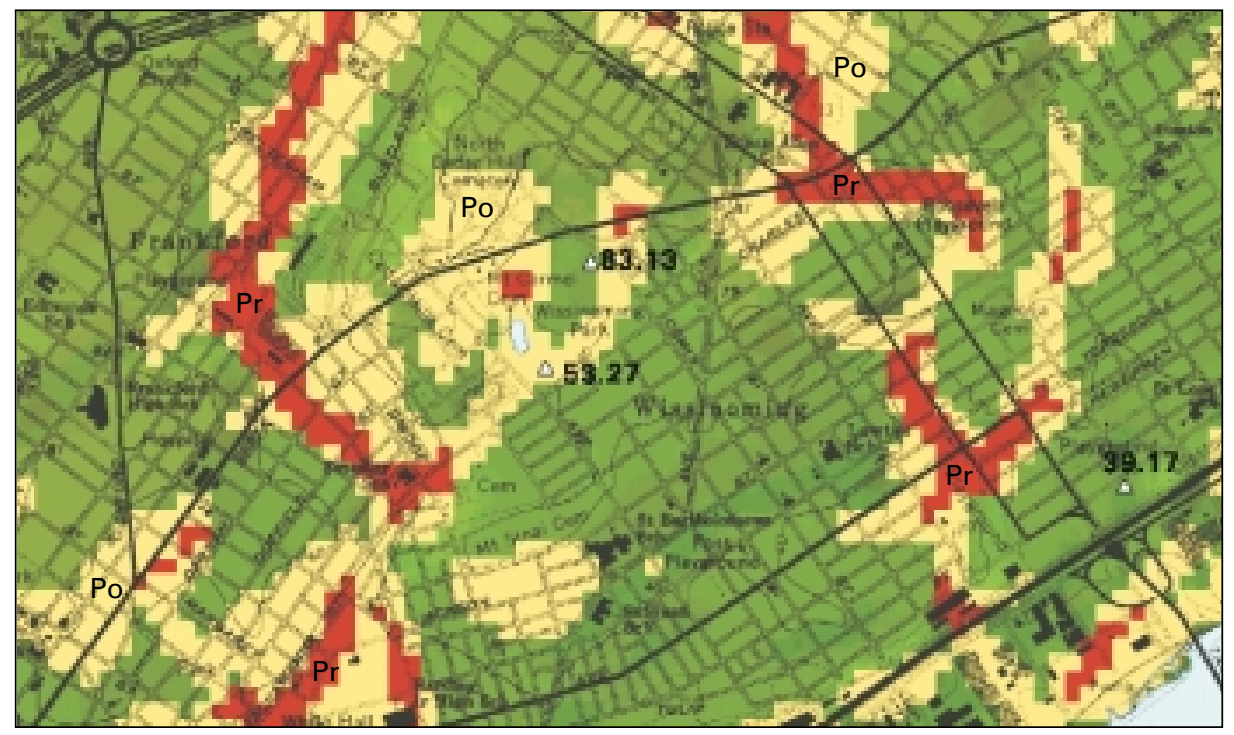

A

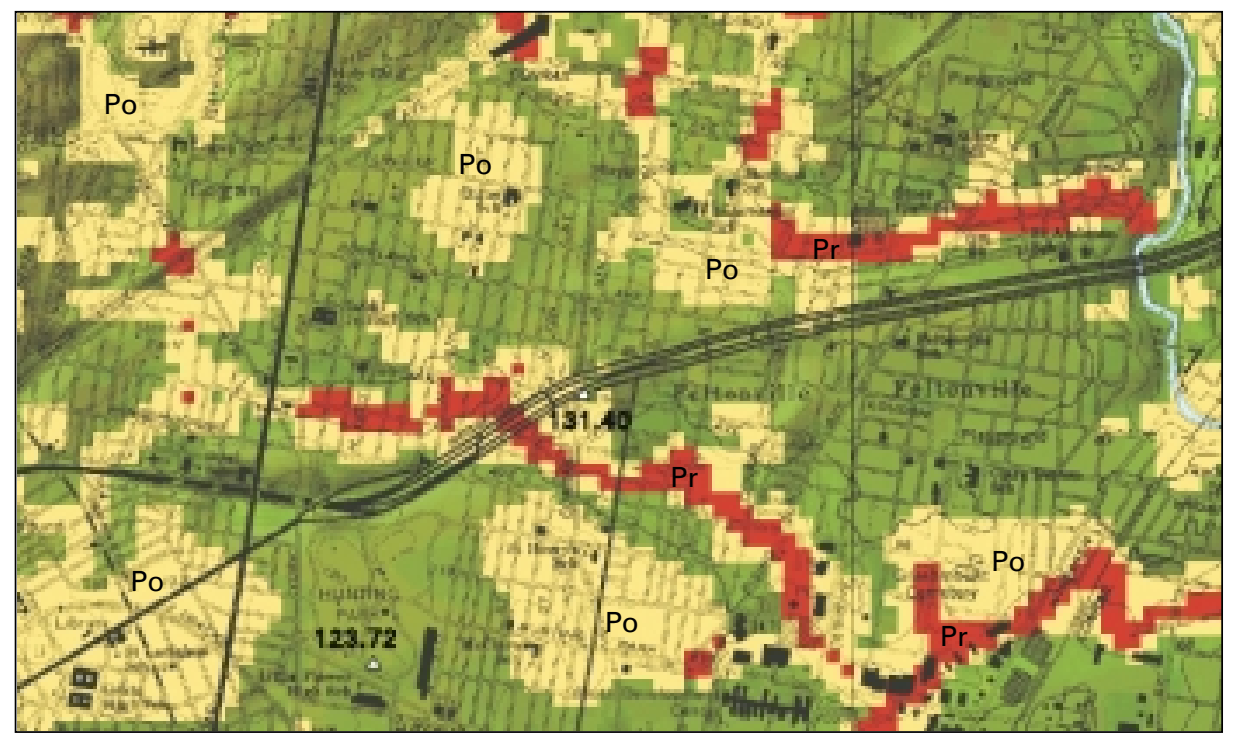

B

Figure 5. Examples from the topographic change map included in USGS Open-File Report 00-224. Areas shaded in yellow and labeled Po have been characterized as possible fill. Areas shaded in red and labeled Pr have been characterized as probable fill. A, Map segment showing historical stream valleys of Wissinoming Creek and Little Tacony Creek. B, Map segment showing historical stream valley of Wingohocking Creek. C, Map segment showing small creek beds and topographically low areas and possible fill along rail lines and interstate highways.

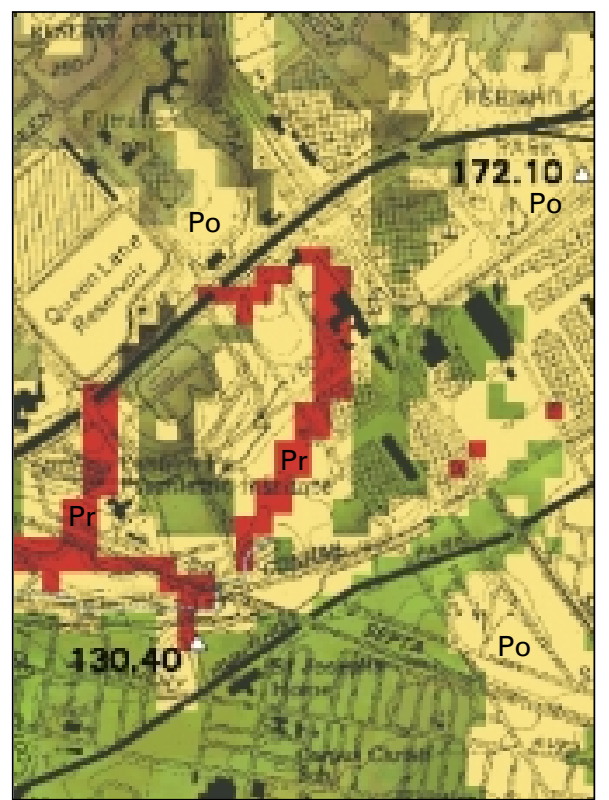

C

\section{References}

Bascom, Florence, Clark, W.B., Darton, N.H., Kummel, H.B., Salisbury, R.D., Miller, B.L., and Knapp, G.N., 1909, Description of the Philadelphia District: U.S. Geological Survey Geologic Atlas, Folio 162, 24 p.

Chirico, P.G., and Epstein, J.B., 2000, Geographic information systems analysis of topographic change in Philadelphia, Pennsylvania, during the last century: U.S. Geological Survey Open-File Report 00-224, one CD-ROM, map scale 1:24,000. (Also available on the web at http://pubs.usgs.gov/openfile/of00224/)

For questions on geology or mapping, please contact the USGS:

Telephone: 1-888-ASK-USGS

USGS web site: http://ask.usgs.gov/

To order a copy of USGS Open-File Report 00-224 or USGS topographic maps, please contact:

USGS Information Services

Box 25286 Denver Federal Center

Denver, CO 80225

Fax: 303-202-4693

Telephone: 1-888-ASK-USGS 